\title{
Aquisphaera giovannonii gen. nov., sp. nov., a planctomycete isolated from a freshwater aquarium
}

\begin{abstract}
Correspondence
Olga Maria Lage

olga.lage@fc.up.pt
\end{abstract}

\author{
Joana Bondoso, ${ }^{1,2}$ Luciana Albuquerque, ${ }^{3}$ M. Fernanda Nobre, ${ }^{4}$ \\ Alexandre Lobo-da-Cunha, ${ }^{2,5}$ Milton S. da Costa ${ }^{4}$ and Olga Maria Lage ${ }^{1,2}$ \\ 'Departamento de Biologia, Faculdade de Ciências, Universidade do Porto, Rua do Campo Alegre \\ $\mathrm{s} / \mathrm{n}^{\circ}, 4169-007$ Porto, Portugal \\ ${ }^{2}$ CIMAR/CIIMAR - Centro Interdisciplinar de Investigação Marinha e Ambiental - Universidade do \\ Porto, Rua dos Bragas, 289, 4050-123 Porto, Portugal \\ ${ }^{3}$ Centro de Neurociências e Biologia Celular, Universidade de Coimbra, 3004-517 Coimbra, \\ Portugal \\ ${ }^{4}$ Departamento de Ciências da Vida, Apartado 3046, Universidade de Coimbra, 3001-401 Coimbra, \\ Portugal \\ ${ }^{5}$ Laboratório de Biologia Celular, Instituto de Ciências Biomédicas Abel Salazar, ICBAS, \\ Universidade do Porto, Largo Abel Salazar 2, 4099-003 Porto, Portugal
}

\begin{abstract}
As part of a study of the diversity of planctomycetes, two novel strains, designated OJF2 ${ }^{\top}$ and OJF8, were isolated from the sediments of a freshwater aquarium. The organisms were chemoheterotrophic, spherical and pink-pigmented, had an optimum growth temperature of about $30-35{ }^{\circ} \mathrm{C}$ and an optimum $\mathrm{pH}$ for growth of around $7.5-8.5$. The predominant fatty acids were $\mathrm{C}_{18: 1} \omega 9 \mathrm{c}$ and $\mathrm{C}_{16: 0}$. The two strains were able to assimilate several sugars and organic acids. $16 \mathrm{~S}$ rRNA gene sequence analysis confirmed the affiliation of these organisms to the phylum 'Planctomycetes'; they showed highest similarity to the type strains of Singulisphaera acidiphila (92.4\%) and Isosphaera pallida (91.9\%). On the basis of physiological, biochemical and chemotaxonomic characteristics, strains $\mathrm{OJF2}{ }^{\top}$ and OJF8 are considered to represent a novel species of a new genus of the order Planctomycetales, for which the name Aquisphaera giovannonii gen. nov., sp. nov. is proposed. The type strain of Aquisphaera giovannonii is OJF2 ${ }^{\top}$ $\left(=\right.$ CECT $7510^{\top}=$ DSM $\left.22561^{\top}\right)$.
\end{abstract}

Members of the phylum 'Planctomycetes' possess many peculiarities not found in other bacteria: they reproduce by budding, have a distinct nucleoid and lack peptidoglycan in the cell wall. At the time of writing, this phylum comprises nine genera with only ten cultured and validly named species (Kulichevskaya et al., 2008, 2007; Schlesner et al., 2004; Ward et al., 2006), although the small number of organisms isolated betrays the great diversity and ubiquity that has been revealed by molecular microbial ecology techniques (Brümmer et al., 2004; Kirkpatrick et al., 2006; Köhler et al., 2008; Kulichevskaya et al., 2006; Shu \& Jiao, 2008; Woebken et al., 2007). The physiological diversity may also be larger than cultured strains suggest, leading us to look for new

Abbreviations: ERIC, enterobacterial repetitive intergenic consensus; NAG, $N$-acetylglucosamine.

The GenBank/EMBL/DDBJ accession numbers for the $16 \mathrm{~S}$ rRNA gene sequences of strains OJF2 ${ }^{\top}$ and OJF8 are D0.986200 and GU123163, respectively.

One supplementary figure and two supplementary tables are available with the online version of this paper. representatives of this group in pure culture. We have therefore attempted to isolate novel planctomycetes from different environments, leading to the recovery of two strains $\left(\mathrm{OJF} 2^{\mathrm{T}}\right.$ and OJF8) from an ornamental freshwater aquarium. In this study we describe the genotypic, phenotypic and phylogenetic characteristics of strains $\mathrm{OJF} 2^{\mathrm{T}}$ and OJF8, which are shown to be related most closely to species of the genera Singulisphaera and Isosphaera.

Strains OJF2 ${ }^{\mathrm{T}}$ and OJF8 were isolated from an ornamental freshwater aquarium containing four fish of the species Pseudotropheus lombardoi and the ornamental plant Anubias barteri 'nana'. Pieces of schist and river sand were heat sterilized before being placed in the aquarium. The water of the aquarium had a $\mathrm{pH}$ around 8.0 and a temperature of $27{ }^{\circ} \mathrm{C}$. The sediments were collected aseptically and washed in sterile $1 \times$ PBS to remove the remaining water from the aquarium, suspended in $1 \mathrm{ml}$ of the same buffer and vortexed to remove the attached bacteria. Aliquots of each sample $(100 \mu \mathrm{l})$ were inoculated into five solid or liquid media (see Supplementary Table S1 available in IJSEM 
Online). For the selective isolation of planctomycetes, the media were supplemented with (per millilitre) $200 \mu \mathrm{g}$ ampicillin, $500 \mu \mathrm{g}$ streptomycin and $20 \mu \mathrm{g}$ cycloheximide. A vitamin solution composed of (per millilitre) $0.1 \mu \mathrm{g}$ cyanocobalamine, $2.0 \mu \mathrm{g}$ biotin, $5.0 \mu \mathrm{g}$ thiamine- $\mathrm{HCl}, 5.0 \mu \mathrm{g}$ Ca pantothenate, $2.0 \mu \mathrm{g}$ folic acid, $5.0 \mu \mathrm{g}$ riboflavin and $5.0 \mu \mathrm{g}$ nicotinamide was added to each medium. The cultures were incubated in the dark at $20{ }^{\circ} \mathrm{C}$. Pure cultures were obtained by subcultivation in the same media and were routinely maintained in PYGV $[0.025 \%$ peptone, $0.025 \%$ yeast extract, $0.025 \%$ glucose supplemented with $20 \mathrm{ml}$ Hutner's basal salts $1^{-1}$ and $10 \mathrm{ml}$ vitamin solution $1^{-1}$ (Staley, 1968)] because this was the most adequate medium for growth of the organisms. PYGV medium with $20 \%(\mathrm{w} / \mathrm{v})$ glycerol was used for long-term storage of cultures at $-80{ }^{\circ} \mathrm{C}$.

To confirm the presence of planctomycetes in the aquarium sediments, CARD-FISH (catalysed reporter deposition fluorescence in situ hybridization) was performed as described by Pernthaler et al. (2002). The type strain of Singulisphaera acidiphila (DSM $18658^{\mathrm{T}}$ ) was obtained from the Deutsche Sammlung von Mikroorganismen und Zellkulturen GmbH, Braunschweig, Germany.

Cell morphology and motility were observed by optical microscopy. Gliding motility and phototaxis were examined on PYGV medium as described by Giovannoni et al. (1987a). For scanning electron microscopy (HITACHI S570), cells in liquid PYGV medium were treated according to Lage et al. (1996). For transmission electron microscopy, cells were harvested from 7-day-old liquid cultures in PYGV, fixed in $2.5 \%(\mathrm{w} / \mathrm{v})$ glutaraldehyde in $0.1 \mathrm{M}$ sodium cacodylate buffer ( $\mathrm{pH} 6.8$ ) for $2 \mathrm{~h}$ and post-fixed in $1 \%(\mathrm{v} / \mathrm{v})$ osmium tetroxide in the same buffer for $4 \mathrm{~h}$. Cells were dehydrated through a graded ethanol series, then propylene oxide and embedded in Epon resin. Ultrathin sections were stained for $10 \mathrm{~min}$ in $1 \%(\mathrm{v} / \mathrm{v})$ uranyl acetate and for $10 \mathrm{~min}$ in Reynolds lead citrate. The sections were examined in a JEOL 100CXII transmission electron microscope. Alternatively, cells were cryopreserved after being transferred to $1.5 \mathrm{~mm}$ diameter and $200 \mu \mathrm{m}$ depth planchettes; they were then immediately cryoimmobilized by using a Leica EMPact high-pressure freezer and freezesubstituted over 3 days at $-90{ }^{\circ} \mathrm{C}$ in anhydrous acetone containing $2 \%(\mathrm{v} / \mathrm{v})$ osmium tetroxide and $0.1 \%(\mathrm{v} / \mathrm{v})$ uranyl acetate and then warmed to room temperature at $5{ }^{\circ} \mathrm{C} \mathrm{h}^{-1}$. After several acetone rinses, samples were infiltrated with Epon resin for 2 days and resin was polymerized at $60{ }^{\circ} \mathrm{C}$ over $48 \mathrm{~h}$. Ultrathin sections were obtained by using a Leica Ultracut UCT ultramicrotome and mounting on Formvar-coated copper grids that were stained with $2 \%(\mathrm{v} / \mathrm{v})$ uranyl acetate in water and in Reynolds lead citrate. Sections were observed in a Tecnai Spirit electron microscope.

Unless otherwise stated, all biochemical and tolerance tests were performed in liquid media at $35{ }^{\circ} \mathrm{C}$ with shaking (200 r.p.m.). Growth of strains OJF2 ${ }^{\mathrm{T}}$ and OJF8 in PYGV, PYGV4, R2A and IMC (Supplementary Table S1) was determined by measuring turbidity at $600 \mathrm{~nm}$. Cells were pre-adapted to each medium for two transfers. All cultures were performed in triplicate. The temperature range for growth was tested from 5 to $45{ }^{\circ} \mathrm{C}$ at $5{ }^{\circ} \mathrm{C}$ intervals in PYGV agar medium. $\mathrm{NaCl}$ tolerance was examined in PYGV agar medium supplemented with $\mathrm{NaCl}$ at concentrations of $0-4 \%$. The $\mathrm{pH}$ range for growth was determined in PYGV medium by using the following buffers: 10 mM MES ( $\mathrm{pH} 5.5$ and 6.5), HEPPSO (pH 7.5 and 8.5) and CAPS (pH 9.5 and 10.5). Results were observed after 7 days. To study vitamin requirements, a modification of M20c medium (Schlesner et al., 2004) consisting of $0.1 \%$ glucose $(\mathrm{w} / \mathrm{v}), 0.1 \%$ Casamino acids $(\mathrm{w} / \mathrm{v})$ and $2 \%$ Hutner's basal salts (v/v) was used. Different vitamin solutions $[1 \%(\mathrm{v} / \mathrm{v})$, omitting one of the abovementioned co-factors at a time] were added to media. Results were recorded after two transfers in the same medium to avoid false positives due to potential cell storage of the vitamins.

Oxidase and catalase reactions, and hydrolysis of starch, casein, Tween 20, Tween 80, aesculin, elastin, arbutin and xylan were determined by using standard methods (Skerman, 1969; Tindall et al., 2007). Additional enzyme activities were assessed by using the API ZYM and API 20E systems, according to the manufacturer's instructions (bioMérieux), for $48 \mathrm{~h}$ or 2 weeks, respectively. Carbon source oxidation was assessed with the Biolog GN2 MicroPlate System. To inoculate the microplates, strains were grown in PYGV agar medium for 1 week, harvested and resuspended in sterile $0.85 \%(\mathrm{w} / \mathrm{v}) \mathrm{NaCl}$. Cell suspensions were sonicated for $2 \mathrm{~min}$ ( $15 \mathrm{~s}$ pulses) in an ice bath to break up the aggregates. The results were assessed after 2 weeks of incubation. Nitrogen source utilization was determined by using a liquid basal medium containing $0.05 \%(\mathrm{w} / \mathrm{v})$ glucose, $0.01 \%(\mathrm{w} / \mathrm{v}) \mathrm{KH}_{2} \mathrm{PO}_{4}$, $20 \mathrm{ml}$ Hutner's basal salts $\mathrm{l}^{-1}$ and $10 \mathrm{ml}$ vitamin solution $1^{-1}$, supplemented with $0.05 \%(\mathrm{w} / \mathrm{v})$ of each of the 20 natural amino acids, as well as peptone, yeast extract, Casamino acids, $N$-acetylglucosamine (NAG), urea, ammonium, nitrate or nitrite. The tests were performed in 24-well plates with $1.5 \mathrm{ml}$ of media. Growth was measured after 1 week. Single-carbon source assimilation tests were performed in a medium composed of Hutner's basal salts $\left(20 \mathrm{ml} \mathrm{l}^{-1}\right)$ to which filter-sterilized ammonium sulfate $\left(0.5 \mathrm{~g} \mathrm{l}^{-1}\right)$, yeast extract $\left(0.1 \mathrm{~g} \mathrm{l}^{-1}\right)$, vitamin solution $\left(10 \mathrm{ml} \mathrm{l}^{-1}\right)$ and the filter-sterilized carbon source $\left(2.0 \mathrm{~g} \mathrm{l}^{-1}\right)$ were added. Growth of the strains on single carbon sources was examined by measuring the turbidity of cultures incubated at $30{ }^{\circ} \mathrm{C}$ in $20 \mathrm{ml}$ screw-capped tubes containing $10 \mathrm{ml}$ of medium for up to 2 weeks. Acid production from carbohydrates was determined by using the API $50 \mathrm{CH}$ system according to the manufacturer's instructions (bioMérieux), with API $50 \mathrm{CHB} / \mathrm{E}$ medium. Results were recorded after 1 and 2 weeks of incubation at $30{ }^{\circ} \mathrm{C}$. Anaerobic growth was assessed in cultures in PYGV medium incubated in anaerobic chambers (GENbox anaer; bioMérieux). 
Pigments were determined in cell-free extracts by sonicating cell suspensions in $0.1 \mathrm{M}$ Tris/ $\mathrm{HCl}, \mathrm{pH} 7.5$, followed by centrifugation to remove debris and unbroken cells. The same procedure was followed to obtain acetone/methanol $(1: 1, \mathrm{v} / \mathrm{v})$ extracts. A Jasco V-530 spectrophotometer was used for spectral analysis.

Cultures for chemotaxonomic analysis were grown in PYGV medium until late exponential phase. Cells for polar lipid analysis were harvested by centrifugation, washed in $0.1 \mathrm{M}$ Tris/ $\mathrm{HCl}, \mathrm{pH} 7.5$, and resuspended in the same buffer. Lipid extraction and two-dimensional TLC were performed according to da Costa et al. (2006). Lipoquinones were extracted from lyophilized cells, purified by TLC and separated by HPLC as described by da Costa et al. (2006). Fatty acid methyl esters were obtained from fresh wet biomass, separated, identified and quantified by using the standard MIS Library Generation Software (Microbial ID) as described previously (da Costa et al., 2006).

For determination of genomic $\mathrm{G}+\mathrm{C}$ content, DNA was isolated as described by Nielsen et al. (1995) and analysed by HPLC (Mesbah et al., 1989). The 16S rRNA gene of strains OJF2 $2^{\mathrm{T}}$ and OJF8 was amplified from genomic DNA extracted with an EZNA Bacterial DNA Isolation kit with universal primers 27F and 1492R (Lane, 1991). The PCR mixture consisted of $1 \times$ PCR buffer, $1.5 \mathrm{mM} \mathrm{MgCl}_{2}, 1 \mathrm{U}$ of GoTaq Flexi DNA polymerase, $200 \mu \mathrm{M}$ of each dNTP, $2 \mu \mathrm{M}$ of each primer and $200 \mathrm{ng}$ of genomic DNA to a final volume of $50 \mu$ l. The thermal PCR program consisted of an initial denaturing step of $5 \mathrm{~min}$ at $95{ }^{\circ} \mathrm{C}, 30$ cycles of $1 \mathrm{~min}$ at $94{ }^{\circ} \mathrm{C}, 1 \mathrm{~min}$ at $52{ }^{\circ} \mathrm{C}$ and $90 \mathrm{~s}$ at $72{ }^{\circ} \mathrm{C}$, and a final extension of $5 \mathrm{~min}$ at $72^{\circ} \mathrm{C}$. PCR products were purified by using the GFX PCR DNA and Gel Band purification kit, cloned into pGEM-T Easy vector and transformed in Escherichia coli DH5 $\alpha$. Plasmid DNA was isolated by using the GenElute Plasmid Miniprep kit, and sequenced at STAB Vida (Oeiras, Portugal). ERIC (enterobacterial repetitive intergenic consensus) PCR profiles were obtained as described by Rademaker \& De Bruijn (1997), by using the primer pair ERIC1 and ERIC2 (Versalovic et al., 1991) except that optimal annealing temperature was $48{ }^{\circ} \mathrm{C}$. PCR products were separated by electrophoresis in $1.5 \%$ agarose gels at $60 \mathrm{~V}$ for $90 \mathrm{~min}$ in $1 \times$ TAE buffer and post-stained with $0.5 \mu \mathrm{g}$ ethidium bromide $\mathrm{ml}^{-1}$.

The 16S rRNA gene sequences obtained were assembled with Vector NTI Advance 10.3, compared with known sequences in GenBank and aligned by using CLUSTAL w (Thompson et al., 1994). Phylogenetic and molecular evolutionary analyses were performed with MEGA version 4 (Tamura et al., 2007). A phylogenetic tree was generated with the neighbour-joining method (Saitou \& Nei, 1987) and its topology was compared with that obtained by using the maximum-parsimony method (Fitch, 1971). Distances were estimated by the Jukes-Cantor method (Jukes \& Cantor, 1969). Bootstrap analysis was based on 1000 resamplings.
Colonies of strains OJF2 ${ }^{\mathrm{T}}$ and OJF8 on PYGV medium were small and light pink (Fig. 1a), but were almost red when grown in media containing $0.1 \%(\mathrm{w} / \mathrm{v})$ NAG supplemented with vitamins and Hutner's basal salts. Similar to Isosphaera pallida, older cultures were attached strongly to the solid medium and were very difficult to remove (Giovannoni et al., 1987a). In the late exponential phase, the organisms formed large pink aggregates resembling snowflakes (Fig. 1b). Reproduction occurred by budding (Fig. 1c). Scanning electron microscopy of the isolates revealed the presence of an extracellular material binding the cells (Fig. 2a). Crateriform pits on the cell surface typical of members of the phylum 'Planctomycetes' were distributed uniformly as in I. pallida and S. acidiphila. Transmission electron microscopy revealed cells with a convoluted paryphoplasm and a riboplasm (pirellulosome) with ribosomes as well as lipid- or glycogen-like granules. The characteristic condensed DNA formed an unmistakable nucleoid (Fig. 2b and d). The general ultrastructural characteristics of strains $\mathrm{OJF}^{\mathrm{T}}$ and OJF8 were consistent with the usual morphology of members of the phylum 'Planctomycetes' (Fuerst, 2005, 2006; Ward et al., 2006). Budding occurred through a narrow passage but the connection between the mother cell and the bud was quite wide, resembling the bud-fission characteristic of some yeasts (Fig. 2a and c). The buds were always surrounded by electron-dense fibrillar material that was lost as the buds matured.

Growth of strains $\mathrm{OJF2}^{\mathrm{T}}$ and OJF8 in liquid media was difficult to measure due to the aggregation of the cells, but similar growth rates in PYGV and IMC, with a doubling time of about 1-2 days, were noted. Growth was inhibited in media with high organic carbon such as R2A and PYGV4. This phenomenon has also been observed with Blastopirellula marina (Schlesner, 1994) and with I. pallida (Giovannoni et al., 1987a). Strains OJF2 ${ }^{\mathrm{T}}$ and OJF8 grew

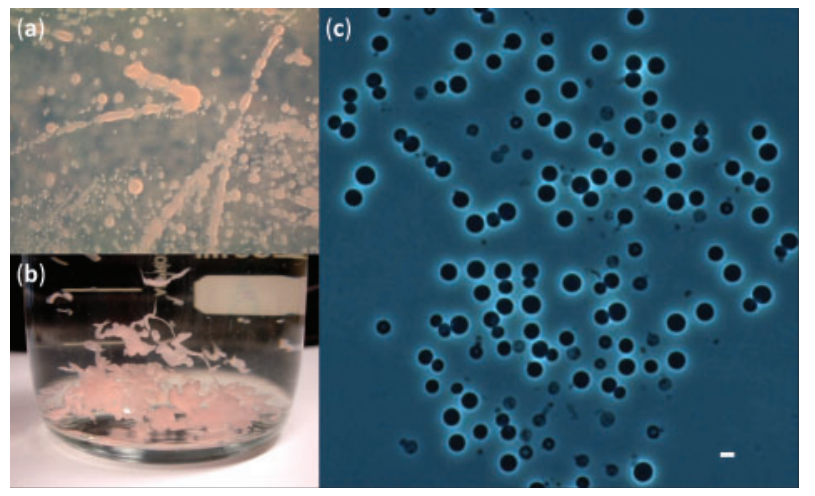

Fig. 1. Morphological characteristics of strain OJF2 ${ }^{\top}$. (a) Colonies grown in PYGV medium showing the pink pigmentation; (b) cell aggregates formed in liquid medium; (c) cell morphology under phase-contrast microscopy showing the round shape of the cells and the budding reproduction. Bar, $2 \mu \mathrm{m}$. 

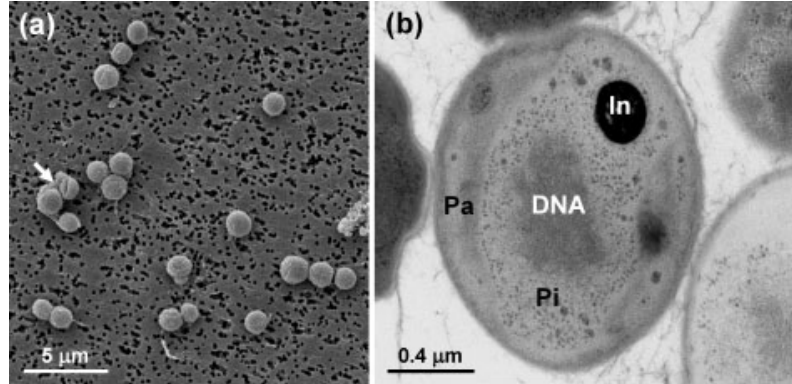

(c)

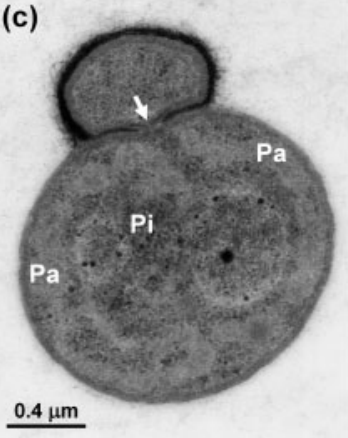

(d)

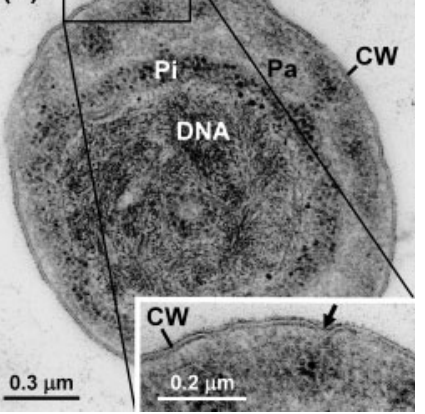

Fig. 2. Scanning (a) and transmission ( $b-d$ ) electron micrographs of cells of strain OJF2 ${ }^{\top}$. (a) Isolated round cells aggregated by extracellular material (arrow). (b-d) Ultrathin sections showing the paryphoplasm $(\mathrm{Pa})$, pirellulosome $(\mathrm{Pi}), \mathrm{DNA}$, inclusions (In) and cell wall $(\mathrm{CW})$ with crater-like structures (d, arrow in inset). The extracellular matrix can be seen in (b). Budding occurred by a narrow passage (c, arrow). The buds were always surrounded by electron-dense fibrillar material that was lost as the buds matured.

at $10-35{ }^{\circ} \mathrm{C}$, with an optimal temperature for growth of around $30{ }^{\circ} \mathrm{C}$. They showed low tolerance to $\mathrm{NaCl}$ (up to $0.25 \%)$ and grew at pH 6.5-9.5, with optimal growth at pH 7.5-8.5.

Strains OJF2 ${ }^{\mathrm{T}}$ and OJF8 were cytochrome oxidase- and catalase-positive. They hydrolysed starch, Tween 20, Tween 80 and gelatin, but not urea, casein, elastin, xylan, aesculin or arbutin. Nitrate was not reduced to nitrite and anaerobic growth was not observed. The Biolog GN2 system indicated that hexoses were the primary carbohydrates oxidized. Carbohydrates and organic acids served as single carbon and energy sources for strains OJF2 ${ }^{\mathrm{T}}$ and OJF8 but amino acids did not serve as single carbon sources under the conditions examined for single carbon source assimilation. The strains utilized several amino acids and proteinaceous supplements as a source of nitrogen. Of the vitamins tested, only vitamin $\mathrm{B} 12$ was required by strains $\mathrm{OJF2} 2^{\mathrm{T}}$ and OJF8. Absorbance spectra of crude extracts and of extracts in acetone/ methanol $(1: 1, \mathrm{v} / \mathrm{v})$ revealed, respectively, the presence of two peaks at 341 and $408 \mathrm{~nm}$ or 374 and $408 \mathrm{~nm}$, and a major peak at $494 \mathrm{~nm}$ which corresponded to carotenoids.
Phosphatidylcholine, phosphatidylglycerol and diphosphatidylglycerol were the major polar lipids of the organisms as detected by TLC (Supplementary Fig. S1). Other unidentified glycolipids and phospholipids were also encountered. Phosphatidylglycerol is a common phospholipid present in the Pirellula-Rhodopirellula-Blastopirellula group and species of the genus Planctomyces (Ward et al., 2006). Phosphatidylcholine has also been found in some planctomycete strains. The major respiratory lipoquinone of all planctomyces examined is, including that of strains $\mathrm{OJF}^{\mathrm{T}}$ and OJF8, menaquinone 6 (MK-6) (Kulichevskaya et al., 2008, 2007; Ward et al., 2006). The fatty acid composition of strains $\mathrm{OJF} 2^{\mathrm{T}}$ and OJF8 showed a predominance of $\mathrm{C}_{18: 1} \omega 9 \mathrm{c}$ and $\mathrm{C}_{16: 0}$, which accounted for about $64 \%$ of the total (Supplementary Table S2). These fatty acids are also the two most abundant fatty acids in the Pirellula-Rhodopirellula-Blastopirellula group, in some strains of Planctomyces (Kerger et al., 1988) and in Singulisphaera (Kulichevskaya et al., 2008). Several planctomycetes, including strains $\mathrm{OJF} 2^{\mathrm{T}}$ and OJF8, contain 3hydroxy fatty acids (Giovannoni et al., 1987b; Sittig \& Schlesner, 1993). $C_{18: 2} \omega 6 c, 12 c$, found in S. acidiphila, was not detected in the new isolates.

Phylogenetic analysis of almost-complete $16 \mathrm{~S}$ rRNA gene sequences revealed that strains $\mathrm{OJF2} 2^{\mathrm{T}}$ and OJF8 were affiliated to the phylum 'Planctomycetes', forming a distinct lineage within the phylum together with the genera Isosphaera and Singulisphaera, with a bootstrap confidence of $100 \%$ (Fig. 3). The two new isolates shared $99.8 \%$ pairwise $16 \mathrm{~S}$ rRNA gene sequence similarity and were related most closely to uncultured bacteria isolated from grassland soil in California and peat soil in Sarobetsu mire, Japan (97.5 and $96.9 \%$, respectively). Levels of $16 \mathrm{~S}$ rRNA gene sequence similarity between strains $\mathrm{OJF2} 2^{\mathrm{T}}$ and OJF8 and the nearest cultured representatives were only $92.4 \%$ with S. acidiphila ATCC BAA- $1392^{\mathrm{T}}$ (Kulichevskaya et al., 2008) and $91.5 \%$ with I. pallida DSM $9630^{\mathrm{T}}$ (Giovannoni et al., 1987a). Phylogenetic analysis with the neighbour-joining, maximum-likelihood and maximum-parsimony methods confirmed the positioning of the new isolates. ERIC profiles of strains $\mathrm{OJF}{ }^{\mathrm{T}}$ and OJF8 were almost identical with a different pattern only in the region between 1000 and $1200 \mathrm{bp}$, showing the genetic similarity between the two isolates. This result confirmed that the isolates are the same strain or are very closely related strains. The $\mathrm{G}+\mathrm{C}$ content of the DNA of strains OJF2 ${ }^{\mathrm{T}}$ and OJF8 was $70.0 \pm 0.35$ and $69.6 \pm 0.45 \mathrm{~mol} \%$ (mean $\pm \mathrm{SD}$ ), respectively.

Based on phylogenetic distinctiveness, genetic characteristics (DNA G $+\mathrm{C}$ content), chemotaxonomic parameters (absence of $\mathrm{C}_{18: 1} \omega 6 c, 12 c$, found at very high levels in $S$. acidiphila) and phenotypic properties (growth temperature range lower than in I. pallida) (Table 1), we suggest that strains OJF2 ${ }^{\mathrm{T}}$ and OJF8 represent a novel species of a new genus within the phylum 'Planctomycetes', for which the name Aquisphaera giovannonii gen. nov., sp. nov. is proposed. 


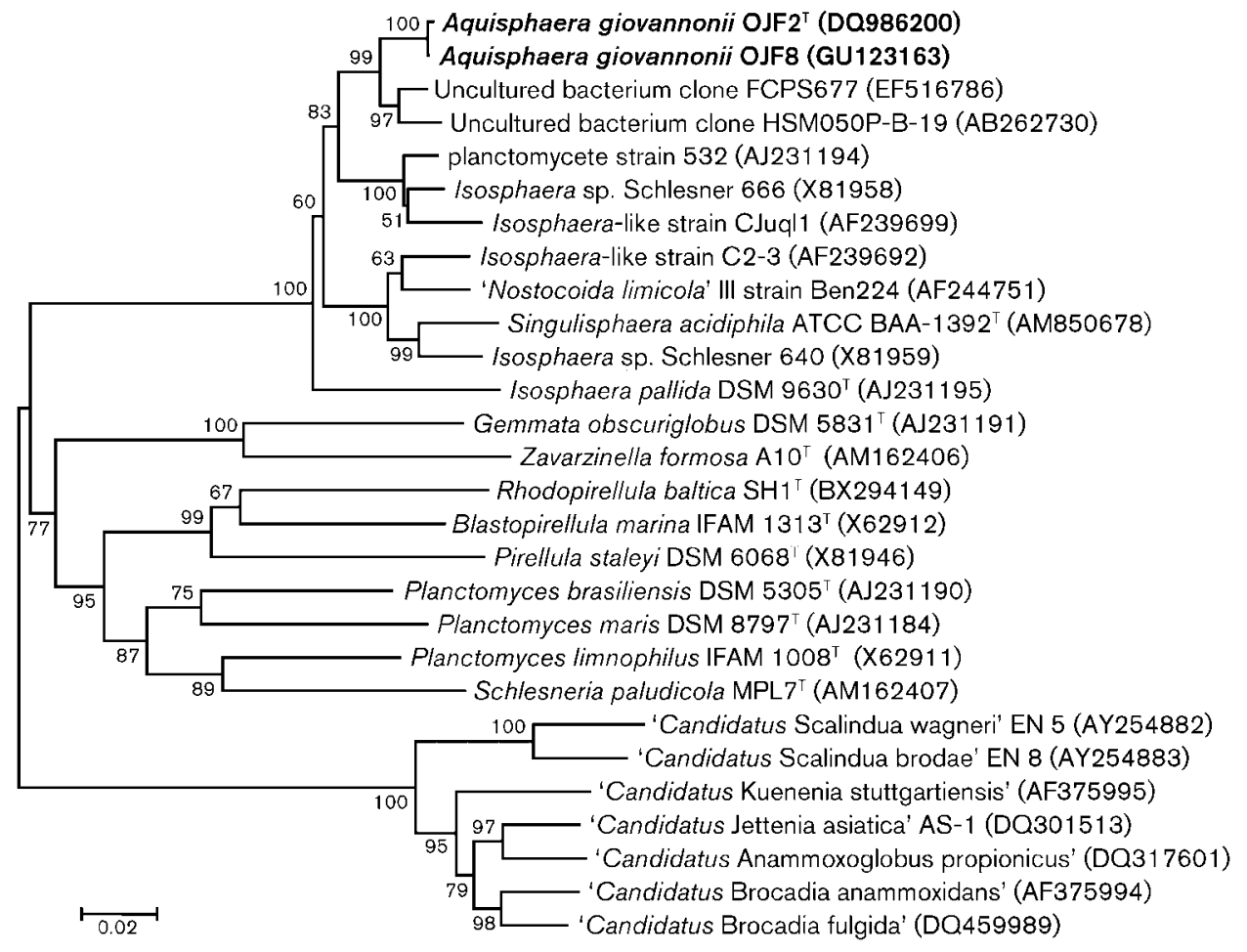

Fig. 3. Phylogenetic relationship between strains OJF2 ${ }^{\top}$ and OJF8 and other representatives of the phylum 'Planctomycetes' based on 16S rRNA gene sequences (accession numbers are shown in parentheses). The tree was reconstructed by using the neighbour-joining algorithm and Jukes-Cantor model. Numbers at nodes are bootstrap values (percentages of 1000 replicates). Bar, 0.02 substitutions per nucleotide position.

\section{Description of Aquisphaera gen. nov.}

Aquisphaera (a.qui.sphae'ra. L. n. aqua water; L. fem. n. sphaera a ball, globe, sphere; N.L. fem. n. Aquisphaera a spherical bacterium living in freshwater).

Cells are Gram-negative, with a cell wall lacking peptidoglycan. Reproduce by budding that resembles budding-fission. Gliding motility and phototaxis are not observed. Chemoheterotrophic, strictly aerobic, catalase- and cytochrome oxidase-positive. The major menaquinone is MK-6.
Predominant phospholipids are phosphatidylcholine and phosphatidylglycerol. This genus is a member of the phylum 'Planctomycetes', order Planctomycetales, family Planctomycetaceae. The type species is Aquisphaera giovannonii.

\section{Description of Aquisphaera giovannonii sp. nov.}

Aquisphaera giovannonii (gi.o.van.no'ni.i. N.L. masc. n. giovannonii of Giovannoni, in honour of the American microbiologist Stephen Giovannoni).

Table 1. Differential characteristics between strain $\mathrm{OJF}^{\top}$ and Isosphaera pallida and Singulisphaera acidiphila

Data for I. pallida and S. acidiphila were taken from Giovannoni et al. (1987a) and Kulichevskaya et al. (2008). ND, No data available.

\begin{tabular}{|c|c|c|c|}
\hline Characteristic & $\mathrm{OJF}^{\mathrm{T}}$ & I. pallida & S. acidiphila \\
\hline Cell size $(\mu \mathrm{m})$ & $1.6-2$ & $2-2.5$ & $1.6-2.5$ \\
\hline Cell arrangement & Single or aggregates & Filaments & Single or pairs \\
\hline Pigmentation & Pink & Pink & Colourless \\
\hline Gliding motility & - & + & - \\
\hline Optimal growth temperature $\left({ }^{\circ} \mathrm{C}\right)$ & $30-35$ & $40-50$ & $15-28$ \\
\hline $\mathrm{NaCl}$ range $(\%, \mathrm{w} / \mathrm{v})$ & $0.0-0.25$ & $\mathrm{ND}$ & $0.2-0.5$ \\
\hline $\mathrm{pH}$ range & $6.5-9.5$ & $7.8-8.8$ & $4.2-7.5$ \\
\hline Vitamin requirement & B12 & $\mathrm{ND}$ & None \\
\hline Presence of $\mathrm{C}_{18: 2} \omega 6 c, 12 c$ & - & ND & + \\
\hline DNA G $+C$ content $(\mathrm{mol} \%)$ & 70.0 & 62.2 & $57.8-59.9$ \\
\hline
\end{tabular}


Possesses the following characteristics in addition to those described for the genus. Cells are spherical, 1.6-2 $\mu \mathrm{m}$ in diameter, non-motile and occur singly or in aggregates held together by extracellular material. Crateriform pits are distributed around the cell surface. Colonies in PYGV are light pink, translucent and smooth. NAG enhances colony pigmentation. Growth does not occur in R2A or PYGV4 but a very large glycocalyx develops during growth, as observed by light and electron microscopy. Extremely large visible cell aggregates are formed. Optimum growth temperature is $30-35{ }^{\circ} \mathrm{C}$ (temperature range between 10 and $35^{\circ} \mathrm{C}$ ) and growth does not occur at 5 or $40{ }^{\circ} \mathrm{C}$. Optimum $\mathrm{pH}$ is $7.5-8.5$ ( $\mathrm{pH}$ range between 6.5 and 9.5) and growth does not occur at $\mathrm{pH} 5.5$ or 10.5 . Does not grow in media containing more than $0.25 \%$ $\mathrm{NaCl}$. Major fatty acids are $\mathrm{C}_{18: 1} \omega 9 c, \mathrm{C}_{16: 0}, \mathrm{C}_{14: 0}$ and $\mathrm{C}_{18: 0 .}$. Degrades starch, Tween 20, Tween 80 and gelatin, but not urea, casein, elastin, xylan, aesculin or arbutin. Positive for alkaline phosphatase, esterase (C4), esterase lipase (C8), leucine arylamidase, valine arylamidase, acid phosphatase, $\alpha$-glucosidase, cystine aminopeptidase, trypsin, $\alpha$-chymotrypsin, $\beta$-glucosidase and $\alpha$-fucosidase (API ZYM); other activities are negative. Produces acetoin but not indole or $\mathrm{H}_{2} \mathrm{~S}$. Arginine dihydrolase, lysine and ornithine decarboxylases are absent. Nitrate is not reduced to nitrite. Assimilates D-glucose D-fructose, D-galactose, Lrhamnose, L-fucose, D-ribose, D-arabinose, L-arabinose, sucrose, maltose, lactose, cellobiose, trehalose, D-mannitol, $\alpha$-ketoglutarate, acetate, pyruvate and D-glucoronate, but not L-sorbose, D-xylose, raffinose, glycerol, ribitol, xylitol, sorbitol, myo-inositol, erythritol, D-arabitol, L-arabitol, succinate, citrate, benzoate, fumarate, formate, aspartate, glutamate, L-alanine, L-asparagine, glycine, L-histidine, L-lysine, proline, L-glutamine, L-arginine, L-serine, valine, L-phenylalanine, L-leucine, L-isoleucine, L-ornithine, methionine or L-threonine. Acid is produced from Darabinose, L-arabinose, D-ribose, D-xylose, L-xylose, D-galactose, D-glucose, D-fructose, D-mannose, L-sorbose, L-rhamnose, melibiose, sucrose, D-lyxose, D-tagatose, D-fucose, L-fucose and potassium 5-ketogluconate (API $50 \mathrm{CH}$ ), but not from any of the other carbon sources. Oxidizes $\alpha$-cyclodextrin, NAG, L-arabinose, D-fructose, Lfucose, D-galactose, D-glucose, D-mannitol, D-mannose, raffinose, L-rhamnose, formic acid, D-glucosaminic acid, Dglucuronic acid, DL-lactic acid, malonic acid, propionic acid, L-phenylalanine, L-threonine and phenylethylamine (Biolog GN2), but not any of the other carbon compounds. Peptone, yeast extract, Casamino acids, NAG, ammonia, asparagine, aspartate, cysteine, glutamine, ornithine, serine and threonine serve as sources of nitrogen. Nitrate, nitrite and urea are not utilized. Vitamin B12 is required for growth. The mean DNA G $+\mathrm{C}$ content of the type strain is $70.0 \pm 0.35 \mathrm{~mol} \%$.

The type strain, OJF2 ${ }^{\mathrm{T}}\left(=\mathrm{CECT} 7510^{\mathrm{T}}=\right.$ DSM $\left.22561^{\mathrm{T}}\right)$, was isolated from the sediments of a freshwater aquarium. OJF8, isolated from a similar source, is a second strain of the species.

\section{Acknowledgements}

This work was supported by FCT and EFP (grant 051/ER/06). We thank Nuno Camboa for the collection of samples, Fernando Tavares for molecular biology facilities, Jens Harder's group (Thomas Holler for CARD-FISH) and Josep Gasol's group for SEM. We thank Jean Euzéby for help with etymology. We also thank Peter Schumann from the DSMZ for GC-MS analysis.

\section{References}

Brümmer, I. H. M., Felske, A. D. M. \& Wagner-Döbler, I. (2004). Diversity and seasonal changes of uncultured Planctomycetales in river biofilms. Appl Environ Microbiol 70, 5094-5101.

da Costa, M. S., Nobre, M. F. \& Wait, R. (2006). The chemotaxonomic analysis of lipids from extremophilic bacteria. Methods Microbiol 35, 127-159.

Fitch, W. M. (1971). Towards defining the course of evolution: minimum change for a specific tree topology. Syst Zool 20, 406-416.

Fuerst, J. A. (2005). Intracellular compartmentation in planctomycetes. Annu Rev Microbiol 59, 299-328.

Fuerst, J. A. (2006). Membrane-bounded nucleoids and pirellulosomes of Planctomycetes. In Complex Intracellular Structures in Prokaryotes, pp. 229-257. Edited by J. M. Shively. Berlin: SpringerVerlag.

Giovannoni, S. J., Schabtach, E. \& Castenholz, R. W. (1987a). Isosphaera pallida, gen. and comb. nov., a gliding, budding eubacterium from hot springs. Arch Microbiol 147, 276-284.

Giovannoni, S. J., Godchaux, W., III, Schabtach, E. \& Castenholz, R. W. (1987b). Cell wall and lipid composition of Isosphaera pallida, a budding eubacterium from hot springs. J Bacteriol 169, 2702-2707.

Jukes, T. H. \& Cantor, C. R. (1969). Evolution of protein molecules. In Mammalian Protein Metabolism, vol. 3, pp. 21-132. Edited by H. N. Munro. New York: Academic Press.

Kerger, B. D., Mancuso, C. A., Nichols, P. D., White, D. C., Langworthy, T., Sittig, M., Schlesner, H. \& Hirsch, P. (1988). The budding bacteria, Pirellula and Planctomyces, with atypical 16S rRNA and absence of peptidoglycan, show eubacterial phospholipids and uniquely high proportions of long chain beta-hydroxy fatty acids in the lipopolysaccharide lipid A. Arch Microbiol 149, 255-260.

Kirkpatrick, J., Oakley, B., Fuchsman, C., Srinivasan, S., Staley, J. T. \& Murray, J. W. (2006). Diversity and distribution of Planctomycetes and related bacteria in the suboxic zone of the Black Sea. Appl Environ Microbiol 72, 3079-3083.

Köhler, T., Stingl, U., Meuser, K. \& Brune, A. (2008). Novel lineages of Planctomycetes densely colonize the alkaline gut of soil-feeding termites (Cubitermes spp.). Environ Microbiol 10, 1260-1270.

Kulichevskaya, I. S., Pankratov, T. A. \& Dedysh, S. N. (2006). Detection of representatives of the Planctomycetes in Sphagnum peat bogs by molecular and cultivation methods. Microbiology (English translation of Mikrobiologiia) 75, 329-335.

Kulichevskaya, I. S., Ivanova, A. O., Belova, S. E., Baulina, O. I., Bodelier, P. L., Rijpstra, W. I., Sinninghe Damsté, J. S., Zavarzin, G. A. \& Dedysh, S. N. (2007). Schlesneria paludicola gen. nov., sp. nov., the first acidophilic member of the order Planctomycetales, from Sphagnum-dominated boreal wetlands. Int J Syst Evol Microbiol 57, 2680-2687.

Kulichevskaya, I. S., Ivanova, A. O., Baulina, O. I., Bodelier, P. L. E., Damsté, J. S. S. \& Dedysh, S. N. (2008). Singulisphaera acidiphila gen. nov., sp. nov., a non-filamentous, Isosphaera-like planctomycete from acidic northern wetlands. Int J Syst Evol Microbiol 58, 1186-1193. 
Lage, O. M., Parente, A. M., Vasconcelos, M. T. S. D., Gomes, C. A. R. \& Salema, R. (1996). Potential tolerance mechanisms of Prorocentrum micans (Dinophyceae) to sublethal levels of copper. J Phycol 32, 416-423.

Lane, D. J. (1991). 16S/23S rRNA sequencing. In Nucleic Acid Techniques in Bacterial Systematics, pp. 115-175. Edited by E. Stackebrandt \& M. Goodfellow. Chichester: Wiley.

Mesbah, M., Premachandran, U. \& Whitman, W. B. (1989). Precise measurement of the $\mathrm{G}+\mathrm{C}$ content of deoxyribonucleic acid by highperformance liquid chromatography. Int J Syst Bacteriol 39, 159-167.

Nielsen, P., Fritze, D. \& Priest, F. G. (1995). Phenetic diversity of alkaliphilic Bacillus strains: proposal for nine new species. Microbiology 141, 1745-1761.

Pernthaler, A. J., Pernthaler, J. \& Amann, R. (2002). Fluorescence in situ hybridization and catalyzed reporter deposition for the identification of marine bacteria. Appl Environ Microbiol 68, 3094-3101.

Rademaker, J. L. W. \& De Bruijn, F. J. (1997). Characterization and classification of microbes by REP-PCR genomic fingerprinting and computer-assisted pattern analysis. In DNA Markers: Protocols, Applications and Overviews, pp. 151-171. Edited by G. CaetanoAnollés \& P. M. Gresshoff. New York: Wiley.

Saitou, N. \& Nei, M. (1987). The neighbor-joining method: a new method for reconstructing phylogenetic trees. Mol Biol Evol 4, 406-425.

Schlesner, H. (1994). The development of media suitable for the microorganisms morphologically resembling Planctomyces spp., Pirellula spp., and other Planctomycetales from various aquatic habitats using dilute media. Syst Appl Microbiol 17, 135-145.

Schlesner, H., Rensmann, C., Tindall, B. J., Gade, D., Rabus, R., Pfeiffer, S. \& Hirsch, P. (2004). Taxonomic heterogeneity within the Planctomycetales as derived by DNA-DNA hybridization, description of Rhodopirellula baltica gen. nov., sp. nov., transfer of Pirellula marina to the genus Blastopirellula gen. nov. as Blastopirellula marina comb. nov. and emended description of the genus Pirellula. Int J Syst Evol Microbiol 54, 1567-1580.

Shu, Q. \& Jiao, N. (2008). Different Planctomycetes diversity patterns in latitudinal surface seawater of the open sea and in sediment. J Microbiol 46, 154-159.
Sittig, M. \& Schlesner, H. (1993). Chemotaxonomic investigation of various prosthecate and/or budding bacteria. Syst Appl Microbiol 16, 92-103.

Skerman, V. B. D. (1969). Abstracts of Microbiological Methods. New York: Wiley.

Staley, J. T. (1968). Prosthecomicrobium and Ancalomicrobium: new prosthecate freshwater bacteria. J Bacteriol 95, 1921-1942.

Tamura, K., Dudley, J., Nei, M. \& Kumar, S. (2007). MEGA4: molecular evolutionary genetics analysis (MEGA) software version 4.0. Mol Biol Evol 24, 1596-1599.

Thompson, J. D., Higgins, D. G. \& Gibson, T. J. (1994). CLUSTAL W: improving the sensitivity of progressive multiple sequence alignment through sequence weighting, position-specific gap penalties and weight matrix choice. Nucleic Acids Res 22, 4673-4680.

Tindall, B. J., Sikorski, J., Smibert, R. A. \& Krieg, N. R. (2007). Phenotypic characterization and the principles of comparative systematics. In Methods for General and Molecular Microbiology, 3rd edn, pp. 330-393. Edited by C. A. Reddy, T. J. Beveridge, J. A. Breznak, G. Marzluf, T. M. Schmidt \& L. R. Snyder. Washington, DC: American Society for Microbiology.

Versalovic, J., Koeuth, T. \& Lupski, J. R. (1991). Distribution of repetitive DNA sequences in eubacteria and application to fingerprinting of bacterial genomes. Nucleic Acids Res 19, 68236831.

Ward, N., Staley, J. T., Fuerst, J. A., Giovannoni, S., Schlesner, H. \& Stackebrandt, E. (2006). The order Planctomycetales, including the genera Planctomyces, Pirellula, Gemmata and Isosphaera and the Candidatus genera Brocadia, Kuenenia and Scalindua. In The Prokaryotes: a Handbook on the Biology of Bacteria, vol. 7, pp. 757793. Edited by M. Dworkin, S. Falkow, E. Rosenberg, K. H. Schleifer \& E. Stackebrandt. New York: Springer.

Woebken, D., Teeling, H., Wecker, P., Dumitriu, A., Kostadinov, I., Delong, E. F., Amann, R. \& Glöckner, F. O. (2007). Fosmids of novel marine Planctomycetes from the Namibian and Oregon coast upwelling systems and their cross-comparison with planctomycete genomes. ISME J 1, 419-435. 